\title{
International Registrations of Cultivar Names for Unassigned Woody Genera
}

\author{
Donald G. Huttleston ${ }^{1}$ \\ Longwood Gardens, Box 501, Kennett Square, PA 19348-0501, USA
}

During 1990, nine cultivar names in unassigned woody genera were registered. Anyone who is involved in the origination or introduction of new cultivars of ornamental plants is urged to assure that the names are registered with a view toward nomenclatural stabilization. A list of the International Registration Authorities is available from the American Association of Botanical Gardens and Arboreta (AABGA), 786 Church Road, Wayne, PA 19087, USA.

Baccharis magellanica (Lam.) Pers. 'Inca Gem'. Straley 1982. Registered 19 Mar. 1990. Registrant: Gerald B. Straley, Univ. of British Columbia Botanical Garden, 6501 NW Marine Dr., Vancouver, BC V6T 1W5, Canada. The original plant was selected by the staff in the UBC Botanical Garden in 1982 because of its dense, low, spreading, evergreen habit. It is a male clone with only moderately attractive, cream-white, short-lived flowers. An 8-year-old plant was $15 \mathrm{~cm}$ tall with a $1-\mathrm{m}$ spread. It does well in well-drained soils in sun or light shade. It is hardy to USDA Zones 6 or 7. It will be introduced commercially in 1992.

Clethra alnifolia L. 'Hummingbird'. Feist 1978. Registered 31 Oct. 1990. Registrar Richard Feist, P.O. Box 443, Burlington, Kentucky 41005, USA. The original plant was collected in Pine Mountain, Georgia, by Fred Galle in 1978. It is a dwarf and forms a suckering mound $80 \mathrm{~cm}$ high with a spread of $1.5 \mathrm{~m}$. It has deep-green, lustrous leaves and white, fragrant flowers in racemes up to $18 \mathrm{~cm}$ long. It grows rapidly when young and frequently produces flowers on 1year-old rooted cuttings. It thrives in wet to well-drained, acid soil in sun or partial shade. It is hardy in Arnold Arboretum Zones 5-9.

Hibiscus syriacus L. 'Pamela Frances'. Baker 1986. Registered 4 Apr. 1990. Registrant: R.P. Baker, 8 Grove Footpath, Surbiton, Surrey KT58AT, England, UK. The original plant was cultivated in Kingstonupon-Thames, England, and selected in 1986. It forms a singlestemmed, upright, compact shrub about $2 \mathrm{~m}$ tall with glabrous, threelobed, yellow-green leaves. Its 7- to 8-cm flowers, produced from late summer into fall, are white with crimson (RHS 46A) throats and white staminal columns. It prefers noncompacted soil and is hardy to USDA Zone 5.

Lespedeza thunbergii (DC) Nakai 'Gibraltar'. Frederick 1982. Registered 5 Feb. 1990. Registrant William H. Frederick, Jr., Private Gardens Inc., 1454 Ashland Clinton School Road, Hockessin, Delaware 19707, USA. The original plant was selected in the garden of Hugh R. Sharp, Jr., Wilmington, Delaware by Mr. Frederick in 1982 because of its more vigorous growth more lush foliage and more abundant, richer mauve-pink flowers than is usual for the species. It is a suffrutescent, multistemmed plant attaining a height of 2 to $2.5 \mathrm{~m}$. It is very showy when in flower in September. It is hardy in USDA Zones 5-7 and grows best in a sunny, well-drained location.
Maclura pomifera (Raf.) Schneid. 'Wichita'. Pair 1978. Registered 20 July 1990. Registrant: John C. Pair, Kansas State Univ. Horticulture Research Center, 1901 E 95th South, Wichita, Kansas 67233, USA. The original plant, growing wild in Wichita, was selected by Pair in 1978. It is a male, fruitless and thornless (at maturity), vase-shaped tree to $6.5 \mathrm{~m}$. It is drought-tolerant, pest-resistent, and adapted to a wide range of soils and climatic conditions. It is hardy in USDA Zones 5-8 and was commercially introduced in 1990.

Morus alba L. 'Widman Mitchell'. Mitchell 1985. Registered 6 Aug. 1990. Registrant: Nina Mitchell, 7331 Terri Robin Drive, St. Louis, Missouri 63129, USA. The original plant was a chance seedling discovered by Mitchell's late husband Widman Mitchell, in his garden in 1985. It is an extreme dwarf; a 10-year-old plant is only 25 $\mathrm{cm}$ tall and has a $30-\mathrm{cm}$ spread. It should be ideal for Bonsai culture. Its lobed leaves are only $1 \mathrm{~cm}$ long and the internodes are 2 to $3 \mathrm{~mm}$ long. Like members of its species, it is hardy to USDA Zones 4-5.

Oxydendrum arboreum DC.' Chameleon'. Hill 1990. Registered 10 Dec. 1990. Registrant: Mrs. Julian W. Hill, 73 Cokesbury Village, Hockessin, Delaware 19707, USA. Hill selected the original plant in her garden at Vineyard Haven, Massachusetts, in 1990. It is a chance seedling, 32 years old, and is 11 to $12 \mathrm{~m}$ tall with an oval crown. It flowers well and is very variable in fall coloration from season to season, sometimes rich and varied and sometimes none at all due to early leaf fall. It does well in acid, sandy soil and is hardy to USDA Zone 6 . It is being propagated by Briggs Nursery, Inc., Olympia, Washington.

Robinia pseudoacacia L. 'Dean Rossman'. Rossman 1984. Registered 23 Feb. 1990. Registrant: Dean Michael Rossman, RFD 10, Box 214, McLaughlin Drive, Mahopac, New York 10541, USA. Rossman selected a 6-year-old chance seedling in his garden in 1984 because of its pale yellow leaf color, which is better and more persistent in summer than that of 'Frisia'. It is an irregularly columnar tree $7 \mathrm{~m}$ tall with a $3.5-\mathrm{m}$ spread. It has smaller and fewer prickles than the species. It is hardy to USDA Zone 3.

Vaccinium ovatum Pursh 'Thunderbird'. Straley 1975. Registered 23 Feb. 1990. Registrant: Dr. Gerald B. Straley, Univ. of British Columbia Botanical Garden, 6501 NW Marine Dr., Vancouver, BC V6T 1W5, Canada. The original plant, formerly from the wild, was selected in the UBC Botanical Garden by the staff in 1975. The >20year-old shrub is $2 \mathrm{~m}$ tall. It has dark-bronze spring foliage that more or less turns green in summer. It is more floriferous and fructivorous than is usual for the species, though the fruits tend to be sour. It does well in rich, acid soil in sun or partial shade, though it is not heattolerant. It is hardy to USDA Zone 7. It will probably be available commercially in 1991.

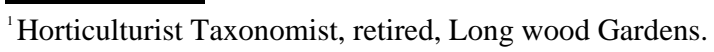

